aerobically with a rat liver homogenate that had been centrifuged for $10 \mathrm{~min}$. at $10000 \mathrm{~g}_{\mathrm{av}}$., in the presence of $\mathrm{NADPH}_{2}$, o-chloroaniline was identified by gas-liquid and thin-layer chromatography as one of the reaction products. Subsequently enzyme activity was found to be located in the soluble fraction of the homogenate (the supernatant after $40 \mathrm{~min}$. at $160000 \mathrm{~g}_{\text {av. }}$ ), the microsomes being devoid of activity. This observation was unexpected, as microsomes contain an $\mathrm{NADPH}_{2}$-dependent azoreductase (EC 1.6.6.7) active against a wide variety of azocompounds (for review see Gillette, 1966).

The activity of the soluble azoreductase was only slightly decreased (10-20\%) when $\mathrm{NADH}_{2}$ was used instead of $\mathrm{NADPH}_{2}$. Moreover, when the two nucleotides were added together at saturating concentrations the two activities were not additive. This suggests the participation of a single enzyme in the reaction. Enzyme activity was inhibited by dicoumarol $\left(\mathrm{I}_{50} 7 \times 10^{-5} \mathrm{M}\right)$, but FAD $\left(8 \times 10^{-5} \mathrm{M}\right)$ produced stimulation $(40 \%)$; the addition of GSH $\left(5 \times 10^{-4} \mathrm{M}\right)$, EDTA $\left(10^{-3} \mathrm{M}\right)$ or albumin $(0.07 \%)$ were without effect. Unlike microsomal azoreductase (Hernandez, Mazel \& Gillette, 1967), enzyme activity was stimulated $(\mathbf{7 0} \%)$ after pretreatment of rats with 3-methylcholanthrene (20mg./kg.) but not with phenobarbitone (100 mg./kg.).

The enzyme was partially purified by fractionation with ammonium sulphate, most of the activity being obtained at 55-65\% saturation. The enzyme thus obtained retained its ability to utilize both $\mathrm{NADPH}_{2}$ and $\mathrm{NADH}_{2}$ with almost equal efficacy.

The properties of this azoreductase, especially with respect to the inhibitory action of dicoumarol and the ability to utilize both nicotinamide nucleotides, are very similar to those of the flavoprotein, DT-diaphorase (Ernster, Danielson \& Ljunngren, 1962), and the response to 3-methylcholanthrene is similar to that of menadione reductase (EC 1.6.99.2) (Huggins \& Fukunishi, 1964), which these authors equate with DT-diaphorase.

Ernster, L., Danielson, L. \& Ljunngren, M. (1962). Biochim. biophys. Acta, 58, 171.

Gillette, J. R. (1966). Advanc. Pharmacol. 4, 219.

Hernandez, P. H., Mazel, P. \& Gillette, J. R. (1967). Biochem. Pharmacol. 16, 1877.

Huggins, C. \& Fukunishi, R. (1964). J. exp. Med. 119, 923.

\section{The Metabolism of 2-Methoxy[ $\left.{ }^{14} \mathrm{C}\right]$ ethyl-} mercury Ghloride

By J. W. Daniel and J. C. Gage. (Imperial Chemical Industries Ltd., Industrial Hygiene Research Laboratories, Alderley Park, Cheshire)

Alkylmercury salts show a marked neurotoxic action that is absent from arylmercury salts (Gage \&
Swan, 1961). This may be attributed to metabolic differences; the alkyl compounds are stable and are only slowly excreted, but the aryl ones are degraded to inorganic mercury (Gage, 1964). Alkoxyalkylmercury salts appear to resemble the aryl more than the alkyl compounds, both in the absence of the characteristic neurotoxic effects, and in the distribution and excretion of radioactivity after the administration of a sample labelled with ${ }^{203} \mathrm{Hg}$ (Ulfvarson, 1962). When 2-methoxy[ $\left.{ }^{14} \mathrm{C}\right]$ ethylmercury chloride is administered subcutaneously to rats, about $6 \%$ of the radioactivity appears as $\mathrm{CO}_{2}$ in the expired air, and if the air is passed through a pyrolysis tube a further $45 \%$ can be recovered in $48 \mathrm{hr}$. About the same amount can be obtained by passing the air through mercury perchlorate solution, a reagent with a specific affinity for olefins (Keller, 1941); the radioactive component is released on acidification and is identical with ethylene by gas chromatography. Within 5 days of dosing, about one-quarter of the dose appears in urine as total mercury and about the same proportion as radioactivity, but chloroform extraction and the kinetics of excretion indicate that only during the first $24-48 \mathrm{hr}$. is there any appreciable excretion of organic mercury. Thereafter the urinary mercury is inorganic. During the first day there is an excretion of organic mercury in bile, but all faecal mercury is inorganic. There is a storage of mercury, but no radioactivity in kidneys, and it seems probable that there is a breakdown of the compound in the tissues generally, and the mercury migrates to the kidneys where it is stored and later excreted. There is no evidence of any enzymic $O$-demethylation of the compound by slices of liver or kidney, and it is likely that the breakdown is a non-enzymic reversal of the process of synthesis, which occurs in the presence of cysteine at low pH (Weiner, Levy \& Mudge, 1962):

$$
\mathrm{C}_{2} \mathrm{H}_{4}+\mathrm{HgCl}_{2}+\mathrm{CH}_{3} \cdot \mathrm{OH} \underset{\mathrm{CH}_{3} \mathrm{O} \cdot \mathrm{C}_{2} \mathrm{H}_{4} \cdot \mathrm{HgCl}+\mathrm{HCl}}{\rightleftharpoons}
$$

Gage, J. C. (1964). Brit. J. industr. Med. 21, 197.

Cage, J. C. \& Swan, A. A. B. (1961). Biochem. Pharmacol. 8, 77.

Keller, R. N. (1941). Chem. Rev. 28, 229.

Ulfvarson, U. (1962). Int. Arch. Gewerbepath. u. Gewerbehyg. $19,412$.

Weiner, I. M., Levy, R. I. \& Mudge, G. H. (1962). J. Pharmacol. 138, 96. 